Steve Peralta, ${ }^{1}$ Keisa Rosales, ${ }^{2}$ Michael J. Robinson, ${ }^{3}$ and Joel Stoltzfus ${ }^{4}$

\title{
Frictional Ignition Testing of Composite Materials
}

\begin{abstract}
The space flight community has been investigating lightweight composite materials for use in propellant tanks for both liquid and gaseous oxygen for space flight vehicles. The use of these materials presents some risks pertaining to ignition and burning hazards in the presence of oxygen. Through hazard analysis process, some ignition mechanisms have been identified as being potentially credible. One of the ignition mechanisms was reciprocal friction; however, test data do not exist that could be used to clear or fail these types of materials as "oxygen compatible" for the reciprocal friction ignition mechanism. Therefore, testing was performed at White Sands Test Facility (WSTF) to provide data to evaluate this ignition mechanism. This paper presents the test system, approach, data results, and findings of the reciprocal friction testing performed on composite sample materials being considered for propellant tanks.
\end{abstract}

KEYWORDS: lightweight composite materials; reciprocal friction ignition; liquid oxygen; gaseous oxygen; materials testing

\section{Introduction}

The concern of material compatibility with oxygen has been brought to the forefront with the growing desire to use polymer composites for propellant tanks. The concern is legitimate for several reasons. First, it is commonly known that materials behave differently with respect to their mechanical (in the service of a cryogen), ignition, and flammability properties when exposed to liquid hydrogen (LH), liquid oxygen (LOX), and gaseous oxygen (GOX). Second, there is a history of accidents that prove materials will burn and burn much more vigorously when exposed to external heat stimuli in the presence of high-concentration and or high-pressure oxygen. To investigate this concern, a procedure was developed that analyzes the LOX tank designs for potential ignition sources and uses standard and specialized tests that simulate the ignition mechanisms. For this reason, an approach to evaluating composite materials was developed and presented in NASA TM 104823 Guide for Oxygen Hazards Analyses on Components and Systems [1]. This procedure begins with an oxygen compatibility assessment of the proposed system in which the design, materials, and operations are evaluated for potential ignition mechanisms. Ignition mechanisms that cannot be eliminated must be addressed by analysis, standard tests, or specialized tests.

After the compatibility assessment was performed, a concern became apparent that frictional heating could occur in the LOX tanks. The NASA Johnson Space Center White Sands Test Facility (WSTF) Oxygen Compatibility Assessment and Component Test Team designed a reciprocal friction test apparatus to rub two composite samples together in pure GOX and

1 Mechanical Engineer, Honeywell Technology Solutions Inc., NASA Johnson Space Center White Sands Test Facility, Las Cruces, NM 88004.

2 Chemical Engineer, Honeywell Technology Solutions Inc., NASA Johnson Space Center White Sands Test Facility, Las Cruces, NM 88004.

3 Associate Technical Fellow, The Boeing Company, Huntington Beach, California, 92647

4 Mechanical Engineer, NASA Laboratories Office, NASA Johnson Space Center White Sands Test Facility, Las Cruces, NM 88004. 
LOX [2]. The purpose of these tests, conducted in 2003, was to investigate the ignition hazard of rubbing (under load) the different adhesives and composite substrates together. This test was developed to simulate the possibility that a baffle or stiffener would partially debond and remain unattached to the wall inside a tank while being exposed to the external vibrations of launch. In addition, it is thought that if LOX penetrates the laminate, there is potential for frictional heating ignition due to relative motion. Reciprocating friction was selected as the ignition mechanism because it has been shown to be a credible ignition mechanism for cryogenic propellant tanks.

This paper provides test data that were obtained directly from these tests by pressure, temperature, and normal load transducers, as well as posttest inspection of the various adhesive and composite substrate samples, and shows their reaction when in the presence of LOX and GOX using the reciprocating friction test.

\section{Background}

Polymer composites are increasingly gaining importance as substitute materials for metals in applications within the aerospace industry. One of the most important advantages is that composite materials are superior to metals in oxidation resistance. Other advantages are that composite materials not only weigh less, but studies and production data by aerospace manufacturers and their development programs show that composite structures are less expensive to produce than metal ones.

The first graphite-epoxy composite cryogenic tanks, which are used on the reusable launch vehicles (RLV), were developed by Boeing in 1987. Improvements on the composite tanks continue today. Although the main focus for the composite tanks was for LH, it was later realized that composite LOX tanks provided additional weight reduction. Since the properties of LH are more extreme than LOX, the only issue that differs is material compatibility. LOX tanks are designed to be pressurized with helium (He). The likelihood of the tank material being exposed to a concentrated GOX environment is low; however, some might rely on oxygen selfpressurization, and it is conceivable that a problem in a He pressurization system might lead to concentrated GOX, or that GOX might somehow concentrate locally. Therefore, the use of composite LOX tanks is very advantageous with respect to launch vehicle weight, but the potential ignition mechanisms in a LOX or GOX environment cannot be overlooked.

\section{Test Approach}

The test program selected various fiberglass-epoxy resin layups (substrates) and adhesive coatings for the composite samples. These substrates and adhesives were chosen because they are the toughened epoxy composites that the industry would use to make composite cryogenic tanks. All of the composite test samples were tested for materials resistance to ignition by reciprocating friction in the presence of oxygen.

For the tests, the objective was to rub the composite samples, uncoated and coated with various adhesives, to determine if there was sufficient heat energy released during the rubbing of the samples to ignite the adhesive and or composite substrate in the presence of GOX and LOX. After the test, the samples were inspected for evidence of ignition with sustained burning and wear. The posttest samples were photographed. Characteristics of an ignition include abrupt temperature, pressure, and displacement increase, and visual determination that the resin is burned away from the matrix (e.g., fuzzy fibers). Characteristics of a no-ignition result include delamination of the matrix but with the fibers still bonded by the attached resin. 


\section{Experimental Procedures}

\section{Test System Description}

The test fixture (Fig. 1) is a stainless steel vessel that can be pressurized up to 400 psig $(2.76 \mathrm{MPa})$. The test cell in which the test fixture is housed can provide LOX to the test system at pressures up to $1000 \mathrm{psi}(6.89 \mathrm{MPa})$. For the heated GOX tests the entire chamber was heated to $300^{\circ} \mathrm{F}\left(149^{\circ} \mathrm{C}\right)$ using an 850 -watt band heater. The temperature was measured and verified with a thermocouple inserted into the chamber. An additional thermocouple was attached to the top of the chamber to ensure that the Teflon ${ }^{\circledR 5}$ seal temperature did not exceed $450{ }^{\circ} \mathrm{F}\left(232{ }^{\circ} \mathrm{C}\right)$.

The reciprocating sample is mounted with two screws to the slip table, which is moved in a "back and forth" motion (reciprocal) via a cam that turns at a speed of $600 \mathrm{rpm}$. The slip table slides on a Monel $^{\circledR 6}$ block that limits the linear motion of the table and also serves as the base of the test fixture.

The stationary sample is mounted to a load shaft such that the two samples are perpendicular to each other. During the test, the load shaft is lowered and pushed against the moving reciprocating sample. The force is controlled via a pneumatic cylinder that is connected to the load shaft by a load cell that measures the normal load. Once the system is set up, the entire test system is operated from a remote control console. The reciprocal friction test is connected to a remote data acquisition system to record shaft speed, chamber pressure and temperature, and sample wear. A closed-circuit video system allows the test conductor to view and record the test system during testing.

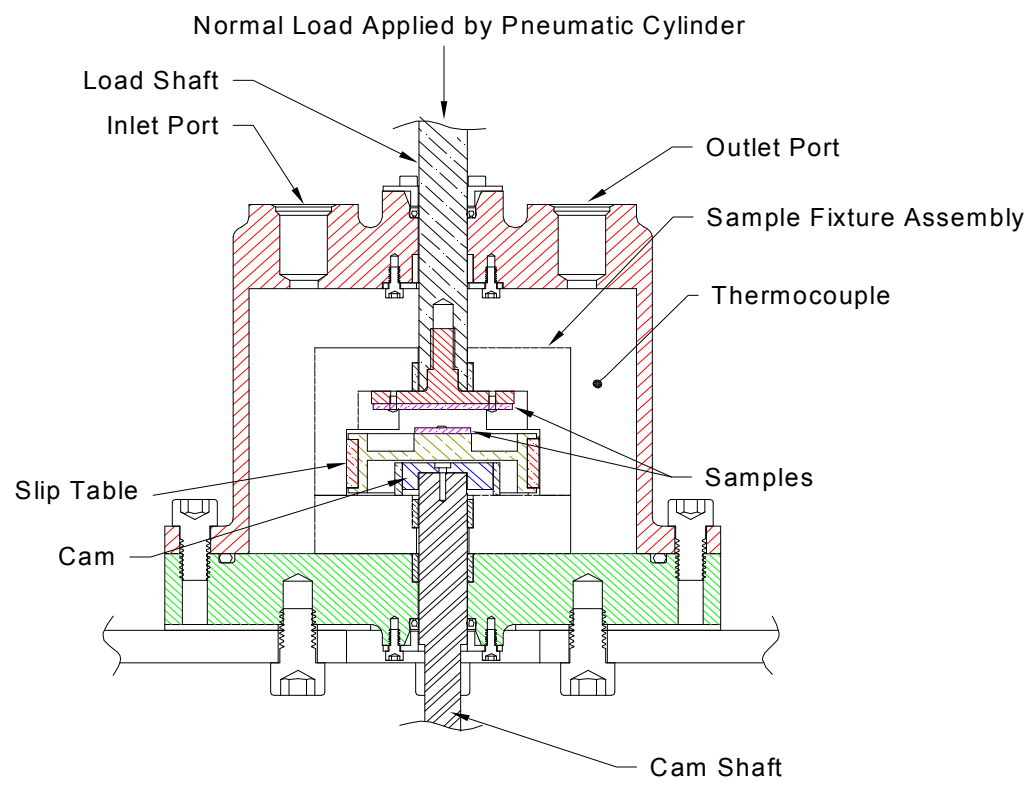

FIG. 1-Reciprocating friction test fixture.

\footnotetext{
${ }^{5}$ Teflon ${ }^{\circledR}$ is a registered trademark of E. I. Du Pont de Nemours and Co., Wilmington, DE.

${ }^{6} \mathrm{Monel}^{\mathbb{B}}$ is a registered trademark of Huntington Alloys Corp., Huntington, WV.
} 


\section{Test Sample Description}

All samples were approximately 0.5 -in. wide, 1.375 -in. long, and .075-in. thick $(1.3 \times 3.49 \mathrm{x}$ $0.19 \mathrm{~cm})$. The samples were oxygen prepared and cleaned by the customer and were tested as received.

\section{Test Procedure}

The test pair specimens were removed from their bags and secured to the slip table and load shaft with two screws each. The test fixture was then reassembled, and the heaters (heaters were only used in GOX tests) were switched on. The test area was cleared of personnel. The chamber was remotely purged and then filled with GOX or LOX to the target pressure. When the gas temperature reached target test temperature, the video system was activated. The test conductor started the test by activating the data acquisition system and cam drive motor. Test run time was determined by either an ignition of the test samples within a time limit of $15 \mathrm{~min}$, or by a reasonable amount of wear through the samples. The normal load was started at $150 \mathrm{lb}_{\mathrm{f}}$ and increased if the sample wear rate was too low. In all tests, either an ignition of the samples or wearing through of the adhesive to the substrate material was the desired result. A test sample ignition was observed by a temperature and/or pressure increase while the test was running or by visual inspection after the test was completed.

After the test, the test system was vented to ambient pressure and the test and system data were stored electronically. Access to the test cell was granted; the heaters (if used) were turned off; the test fixture was disassembled; and the test samples were removed from the test fixture. A posttest inspection of the sample pair was conducted for ignition evidence such as charring or discoloration and wear. The samples were photographed.

\section{Test Conditions}

Test parameters for the reciprocal friction tests were determined by agreement with the customer and then set on the reciprocal friction tester. The tests were conducted in pure LOX and GOX. A cam with 0.25 in. $(64 \mathrm{~cm})$ of travel and a motor speed of $600 \mathrm{rpm}$ was used. Normal forces of 150 to $160 \mathrm{lb}_{\mathrm{f}}$ were used. Testing in LOX was conducted at 100 psig $(0.69 \mathrm{MPa})$ and $-297^{\circ} \mathrm{F}\left(-183{ }^{\circ} \mathrm{C}\right)$. The reciprocal friction tests in GOX were conducted at $100 \mathrm{psig}(0.69 \mathrm{MPa})$ and $300^{\circ} \mathrm{F}\left(149^{\circ} \mathrm{C}\right)$. The test duration for each sample was 15 min unless the top layers of the composite lay-up were damaged or destroyed sooner.

\section{Test Results}

Reciprocating friction tests in a GOX atmosphere showed a significant difference in the severity of the ignitions and wear compared to the tests in a LOX atmosphere. There were no ignitions for any of the combinations of composite materials and adhesives in the LOX tests. This was determined by the data collected from the data acquisition system and from visual inspection of the posttest specimens (Table 1). The characteristics of the data plot shown in Fig. 2 are typical of all the no-ignition results from testing in LOX. A representative posttest sample photo for no-ignition is shown in Fig. 3. 
TABLE 1-Liquid oxygen test results.

\begin{tabular}{clccccc}
\hline $\begin{array}{c}\text { Customer } \\
\#\end{array}$ & \multicolumn{1}{c}{ Material } & $\begin{array}{c}\text { Sample } \\
\text { Orientation }\end{array}$ & $\begin{array}{c}\text { Pressure, } \\
\text { psig }\end{array}$ & Load, lb & $\begin{array}{c}\text { Test } \\
\text { Duration, } \\
\text { min:sec }\end{array}$ & $\begin{array}{c}\text { Ignition \& } \\
\text { Sustained } \\
\text { Burning? }\end{array}$ \\
\hline $02-36955$ & $\begin{array}{l}\text { 977-2 UTL } \\
\text { Vacuum 5.2 mil }\end{array}$ & N/A & 180 & 160 & $10: 00$ & No \\
$02-36956$ & 977-2 Non Autoclave & N/A & 111 & 160 & $10: 00$ & No \\
& 5.2 mil & & & & & \\
$02-36957$ & 3900-2 UTL Vacuum & N/A & 111 & 155 & $10: 00$ & No \\
$02-36958$ & 3900-2 Autoclave & N/A & 140 & 160 & $10: 00$ & No \\
$02-36959$ & 5276-1 Autoclave & N/A & 160 & 160 & $10: 00$ & No \\
$02-36960$ & 977-2 Autoclave & N/A & 100 & 160 & $10: 00$ & No \\
& 2.6 mil & & & & & \\
$02-36969$ & EA-9696, Gry on Blk & Adh/Subst & 100 & 160 & $10: 00$ & No \\
$02-36969$ & EA-9696, Gry on Gry & Adh/Adh & 100 & 160 & $10: 00$ & No \\
$02-36961$ & M72 Non-Autoclave & N/A & 100 & 160 & $10: 00$ & No \\
$02-36970$ & FM-300K, Green to Blk & Adh/Subst & 110 & 160 & $10: 00$ & No \\
$02-36970$ & FM-300K, Grn on Grn & Adh/Adh & 100 & 160 & $10: 00$ & No \\
$02-36971$ & PL 777 & Adh/Adh & 115 & 160 & $10: 00$ & No \\
$02-36971$ & PL 777 & Adh/Subst & 115 & 160 & $10: 00$ & No \\
$02-36972$ & PL 795-1 & Adh/Adh & 110 & 160 & $10: 00$ & No \\
$02-36972$ & PL 795-1 & Adh/Subst & 115 & 160 & $15: 00$ & No \\
$02-36981$ & MB1146A & Adh/Adh & 115 & 160 & $10: 00$ & No \\
$02-36981$ & MB1146A & Adh/Subst & 115 & 160 & $10: 00$ & No \\
\hline
\end{tabular}

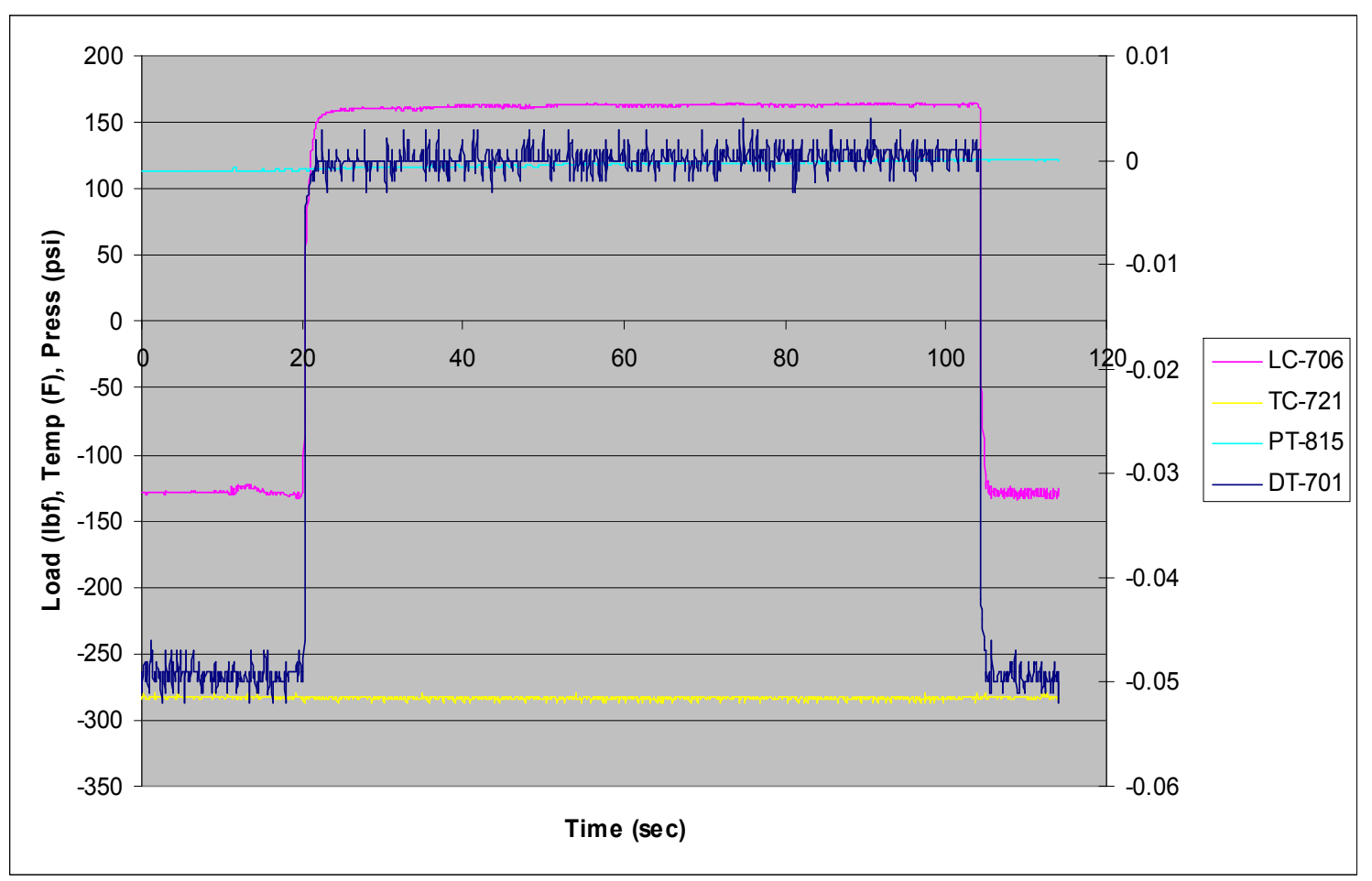

FIG. 2-LOX test data for PL 795-1 (typical for LOX no-ignition results). 


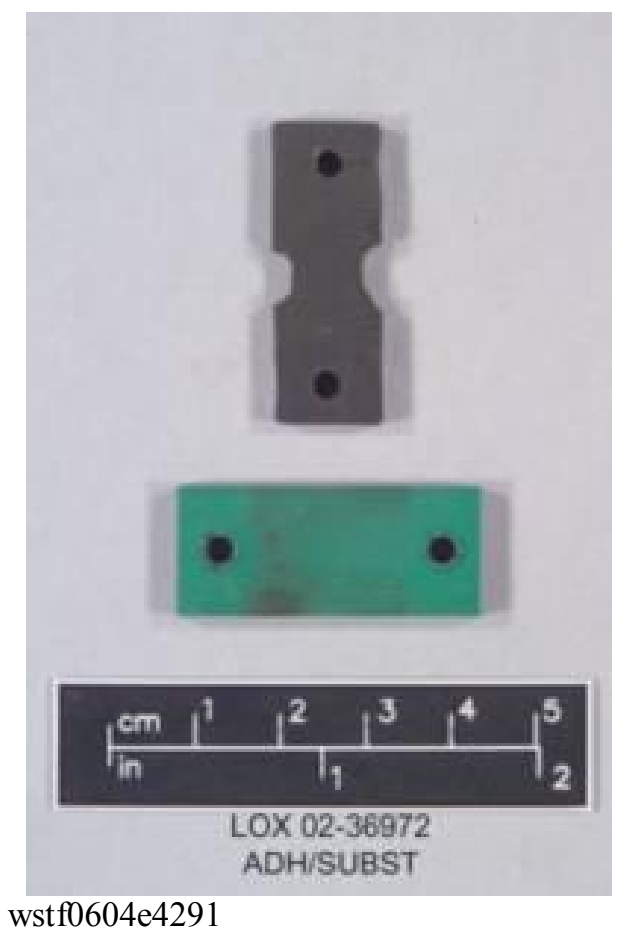

FIG. 3 - Posttest sample for PL 795-1 (typical for LOX no-ignition results).

For the GOX tests, there were both ignitions and no ignitions for combinations of composite materials and adhesives. Table 2 shows the test results for the reciprocating friction tests in GOX. The characteristics in the data plot shown in Fig. 4 are typical of all the ignition results from testing in GOX. An ignition was determined from data showing increase in temperature, pressure and displacement. A representative posttest sample photo for ignition in GOX is shown in Fig. 5.

\section{Discussion}

The initial test sample pair run in LOX was rubbed for 15 min. However, posttest inspection of the sample pair showed virtually no wear at $160 \mathrm{lb}_{\mathrm{f}}$ of normal force (all tests were rubbed at the same frequency), which the test data verified. Because of the lack of wear or degrading of the sample, the test time was reduced to 10 min to save on test costs. It was felt that increasing the run time of the tests would not have produced any beneficial results.

Regardless of rubbing configuration, whether adhesive rubbed on adhesive, adhesive on substrate, or substrate on substrate, all test sample pairs rubbed in LOX showed almost no sign of wear, or ignition.

Test sample pairs that were rubbed in GOX had extremely different results. All sample pairs rubbed in heated GOX were worn through with reciprocal rubbing. As a whole, the run time for the GOX tests was considerably shorter. Some samples were run longer (up to $17 \mathrm{~min}$ ) before completely worn through. The GOX sample pairs were allowed to run longer due to the fact that the heated GOX environment is more severe than the LOX environment. All samples were allowed to run until they were completely worn through, if they didn't ignite and burn first. 
TABLE 2- Gaseous oxygen test results.

\begin{tabular}{|c|c|c|c|c|c|c|c|}
\hline Customer \# & Material & $\begin{array}{c}\text { Sample } \\
\text { Orientation }\end{array}$ & $\begin{array}{l}\text { Pressure, } \\
\text { psig }\end{array}$ & $\begin{array}{l}\text { Temp, } \\
{ }^{\circ} \mathrm{F}\end{array}$ & Load, $\mathrm{lb}_{\mathrm{f}}$ & $\begin{array}{l}\text { Test Duration, } \\
\text { min:sec }\end{array}$ & $\begin{array}{c}\text { Ignition \& } \\
\text { Sustained } \\
\text { Burning? }\end{array}$ \\
\hline $02-36955$ & $\begin{array}{l}\text { 977-2 UTL Vacuum } \\
5.2 \mathrm{mil}\end{array}$ & $\ldots$ & 115 & 360 & 155 & $7: 00$ & No \\
\hline $02-36956$ & $\begin{array}{l}\text { 977-2 Non-Autoclave } \\
5.2 \mathrm{mil}\end{array}$ & $\ldots$ & 90 & 295 & 155 & $9: 00$ & No \\
\hline $02-36957$ & 3900-2 UTL Vacuum & $\ldots$ & 110 & 280 & 160 & 4:00 & No \\
\hline $02-36958$ & 3900-2 Autoclave & $\ldots$ & 110 & 314 & 160 & $5: 00$ & No \\
\hline $02-36959$ & 5276-1 Autoclave & $\ldots$ & 112 & 300 & 160 & $2: 32$ & No \\
\hline $02-36960$ & 977-2 Autoclave $2.6 \mathrm{mil}$ & $\ldots$ & 113 & 290 & 160 & $4: 30$ & No \\
\hline $02-36961$ & M72, Non-Autoclave & $\ldots$ & 114 & 315 & 160 & 5:00 & No \\
\hline $02-36962$ & $950-1$ & $\ldots$ & 115 & 305 & 160 & $3: 30$ & No \\
\hline $02-36963$ & 977-2 Autoclave $5.2 \mathrm{mil}$ & $\ldots$ & 114 & 317 & 160 & 8:09 & No \\
\hline $02-36964$ & E-Beam & $\cdots$ & 115 & 317 & 160 & $1: 31$ & No \\
\hline 02-36965 & 5250 & $\begin{array}{l}\ldots \\
\ldots\end{array}$ & 116 & 334 & 160 & $13: 00$ & No \\
\hline 02-36966 & 5260 & $\ldots$ & 116 & 307 & 162 & $13: 00$ & No \\
\hline $02-36967$ & 8551 & $\ldots$ & 114 & 316 & 172 & $1: 30$ & No \\
\hline 02-36968 & RS-3 & $\ldots$ & 115 & 330 & 174 & $2: 53$ & No \\
\hline $02-36969$ & EA-9696, Gry on Blk & Adh/Subst & 100 & 300 & 160 & $15: 00$ & No \\
\hline $02-36969$ & EA-9696, . Gry to Gry & Adh/Adh & 100 & 300 & 160 & $15: 00$ & No \\
\hline $02-36970$ & M-300K, Grn on Grn & Adh/Adh & 100 & 300 & 160 & $11: 00$ & No \\
\hline $02-36970$ & M-300K, Grn on Blk & Adh/Subst & 100 & 300 & 160 & 9:00 & No \\
\hline $02-36971$ & PL 777 & Adh/Adh & 116 & 300 & 160 & $7: 11$ & No \\
\hline $02-36971$ & PL 777 & Adh/Subst & 102 & 300 & 160 & 2:01 & Yes \\
\hline $02-36972$ & PL 795-1 & Adh/Subst & 116 & 307 & 160 & $1: 49$ & Yes \\
\hline $02-36972$ & PL 795-1 & Adh/Adh & 114 & 305 & 160 & $3: 15$ & No \\
\hline $02-36973$ & HP 655 & Adh/Adh & 115 & 300 & 160 & $6: 00$ & Yes \\
\hline $02-36973$ & HP 655 & Adh/Subst & 115 & 300 & 160 & $17: 00$ & No \\
\hline $02-36974$ & FM 400 & Adh/Adh & 115 & 300 & 160 & $4: 00$ & Yes \\
\hline $02-36974$ & FM 400 & Adh/Subst & 115 & 304 & 160 & $12: 00$ & Yes \\
\hline $02-36975$ & FM 57 & Adh/Subst & 116 & 312 & 160 & $2: 31$ & Yes \\
\hline $02-36975$ & FM 57 & Adh/Adh & 115 & 330 & 161 & $2: 38$ & Yes \\
\hline $02-36976$ & FM 379 & Adh/Subst & 116 & 308 & 160 & $17: 11$ & No \\
\hline $02-36976$ & FM 379 & Adh/Adh & 117 & 300 & 160 & $17: 12$ & No \\
\hline $02-36977$ & FM 300-2 & Adh/Adh & 116 & 314 & 160 & $15: 00$ & No \\
\hline 02-36977 & FM 300-2 & Adh/Subst & 116 & 315 & 160 & $17: 00$ & No \\
\hline $02-36978$ & FM 1146 & Adh/Adh & 116 & 310 & 160 & $17: 43$ & Yes \\
\hline $02-36978$ & FM 1146 & Adh/Subst & 116 & 300 & 160 & $9: 33$ & Yes \\
\hline $02-36979$ & FM 2550 & Adh/Adh & 115 & 321 & 160 & 17.28 & No \\
\hline $02-36979$ & FM 2550 & Adh/Subst & 116 & 300 & 160 & 17.10 & No \\
\hline $02-36980$ & HT 424 & Adh/Adh & 116 & 302 & 160 & $1: 38$ & Yes \\
\hline $02-36980$ & HT 424 & Adh/Subst & 116 & 300 & 160 & $17: 12$ & No \\
\hline $02-36981$ & MB1146A & Adh/Adh & 116 & 323 & 160 & $3: 30$ & No \\
\hline $02-36981$ & MB1146A & Adh/Subst & 116 & 322 & 160 & $2: 57$ & No \\
\hline
\end{tabular}




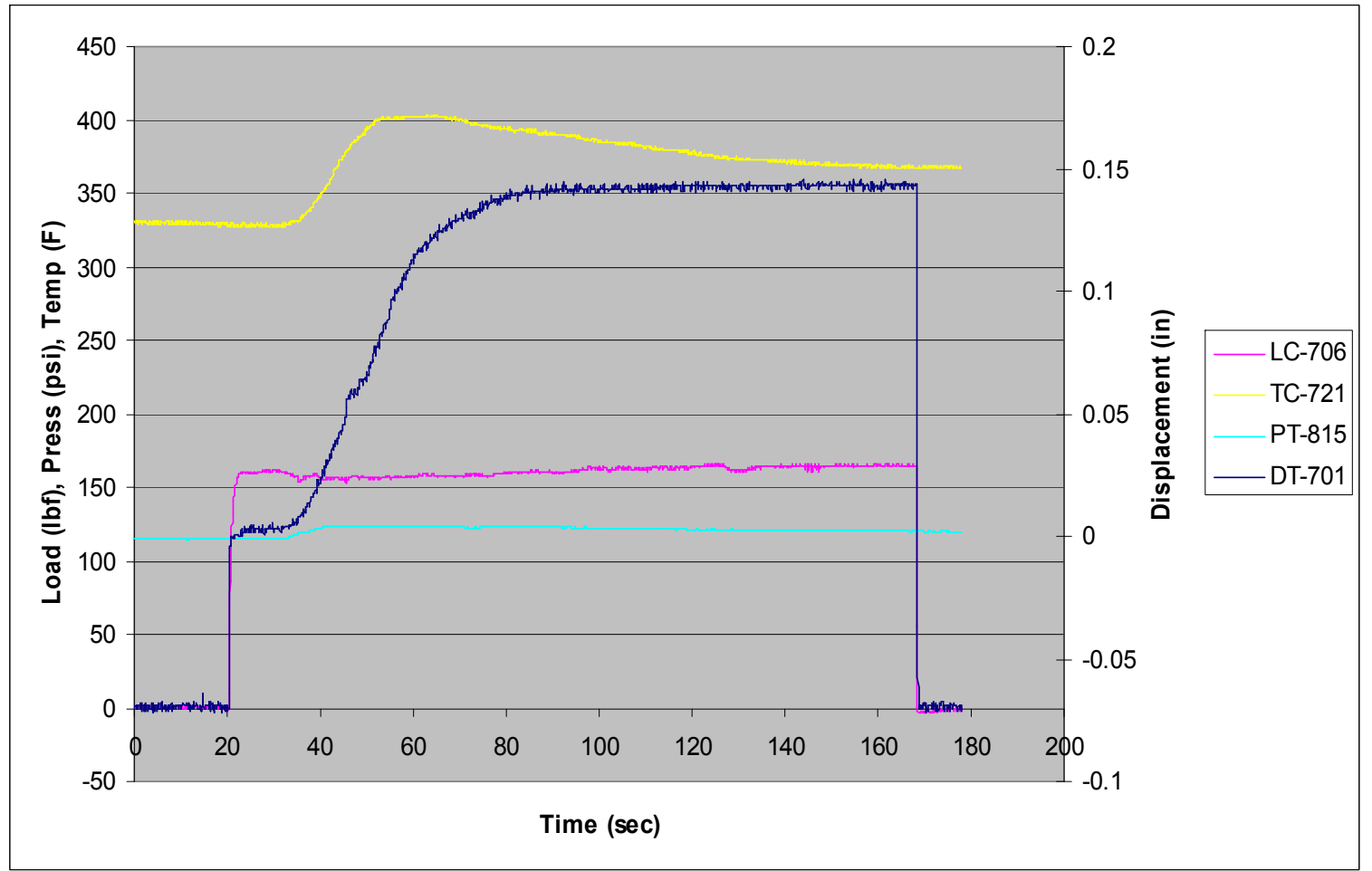

FIG. 4- Gaseous Oxygen Test Data for FM 57 (Adh/Adh) (typical for all GOX ignition results).

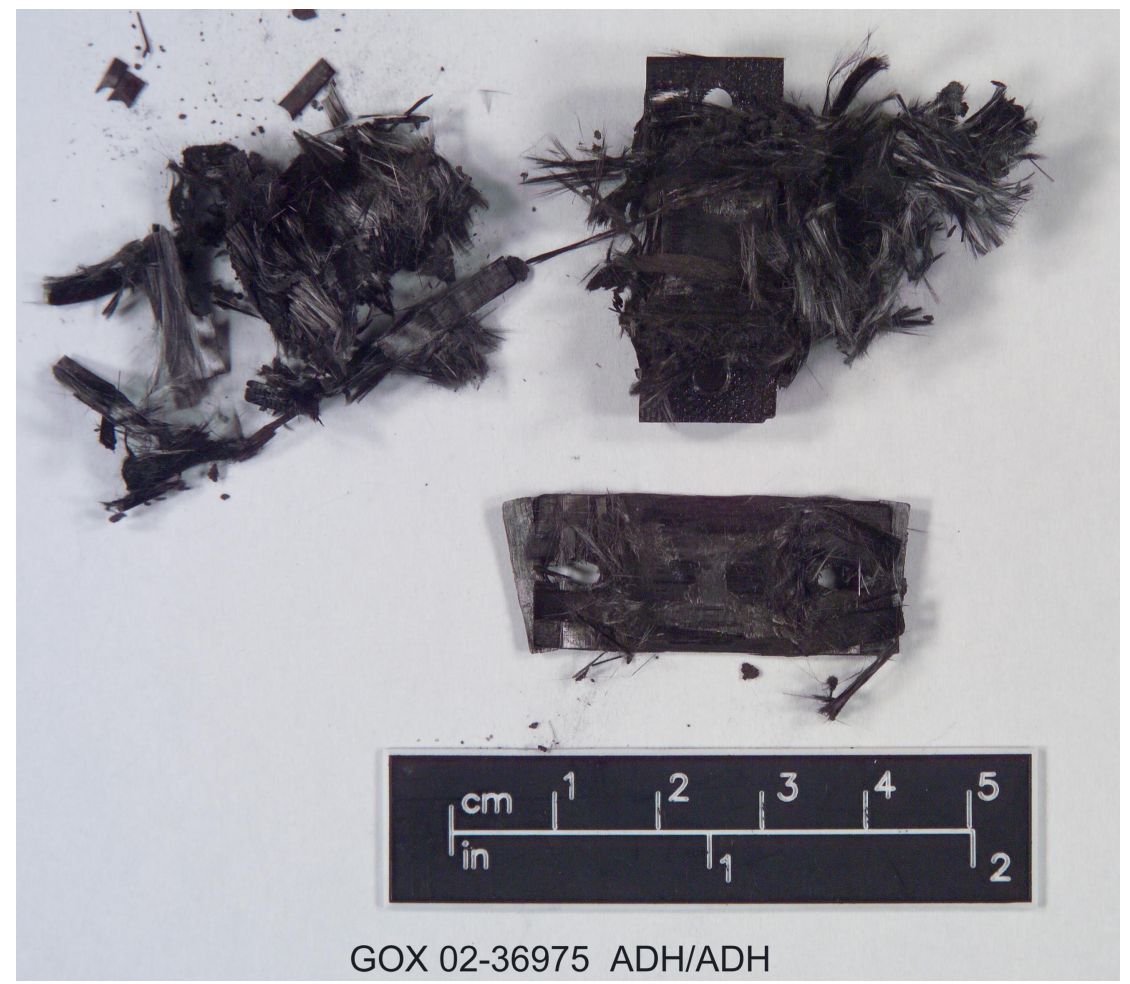

FIG. 5-Posttest sample for FM 57 (Adh/Adh) (typical for all GOX ignition results). 
The sample pairs that did ignite and burn exhibited the typical data pattern shown in Fig. 4. Both the temperature and pressure increased (TC-721, PT-815). Very quickly after the rise of both of these measurements, the displacement (DT-701) would then spike as well. Once the displacement spiked, the test was shut off. Post-inspection of these ignited samples showed the reason for the spike in the displacement. These samples (as typically shown in Fig. 5) showed evidence of the epoxy resin and or adhesive consumed. What was left was a "fluffy pile" of glass fibers.

Samples that did not ignite and burn had a closely similar posttest result; however, the data collected for those samples did not have temperature and pressure increases. Also, upon further inspection the "pile" that was left after rubbing still showed resin bonded with the glass fibers and did not delaminate in the same way as the burned samples. It is also noted that all test sample pairs that indicated ignition and burning included some type of adhesive.

\section{Summary}

Based on the results of the LOX and GOX reciprocating friction tests conducted during 2003 on various epoxy/adhesive coatings for composite materials, ignition of the composite test samples did not occur in a LOX atmosphere. This was regardless of the sample orientation, whether it was adhesive on substrate or adhesive on adhesive rubbed together. Test samples also showed almost no sign of wear after 10 min of rubbing at $160 \mathrm{lb}_{\mathrm{f}}$. It is postulated that the cold liquid temperature of the LOX environment contributed to this result. Most likely the liquid provided a "lubricant" between the rubbing surfaces and was able to carry off any heat developed from the friction.

A combination of ignitions and no ignitions did occur in a GOX atmosphere. Unlike for LOX, the GOX environment was heated. This added amount of energy should have helped ignite the composite materials. Also, unlike the cold liquid (cryogen), the gaseous environment does not provide any kind of "lubricant" between the rubbing surfaces. Therefore, the coefficient of friction is thought to be much higher between the sample pairs in a gaseous environment than in that of the liquid.

Although the chance of a propellant tank being exposed to GOX is low, it is apparent that, under the conditions in this test program, composite materials are susceptible to a reciprocal friction ignition mechanism. It should be noted that, although not out of the realm of possibility, the test parameters chosen in this test program were rather arbitrary with regard to the normal load applied and frequency of rubbing.

Because the test results confirmed that frictional ignition and burning could occur in either a LOX or GOX environment, more testing should be done. Additional testing on these materials should more closely resemble actual conditions that could occur inside a propellant tank. The test parameters that would need closer attention are the normal loads and rubbing frequencies that a tank might actually see in a launch environment.

\section{References}

[1] NASA TM 104823, "Guide for Oxygen Hazards Analyses on Components and Systems," NASA Johnson Space Center, White Sands Test Facility, Las Cruces, NM, October 1996.

[2] Robinson, M. J., Stoltzfus, J. M., and Owens, T. N., "Composite Material Compatibility with Liquid and Gaseous Oxygen," 42nd AIAA/ASMA/ASCE/AHS/ASC Structural Dynamics and Materials Conference, Seattle, Washington, April 16-19, 2001. 